\title{
Management of thermal quantity of hydrogen and sulphur during combustion of Kosova's lignite
}

\author{
Ahmet Haxhiaj, Nyrtene Deva, Mursel Rama \\ Faculty of Geosciences, University of Mitrovica “Isa Boletini”, Mitrovica, Republic of Kosovo \\ Email address \\ ahaxhiaj52@yahoo.com (A. Haxhiaj), ahmet.haxhijaj@uni-pr.edu (A. Haxhijaj)
}

To cite this article:

Ahmet Haxhiaj, Nyrtene Deva, Mursel Rama. Management of Thermal Quantity of Hydrogen and Sulphur During Combustion of Kosova's Lignite. American Journal of Energy Engineering. Vol. 3, No. 1, 2015, pp. 6-10. doi: 10.11648/j.ajee.20150301.12

\begin{abstract}
The aim of paper is analyzing the issue related to the management of effective thermal quantity during lignite combustion and emissions of gases that are product of complete and non-complete combustion of lignite in the boilers. The real thermal amount of total burning lignite is $7524 \mathrm{~kJ} \mathrm{~kg}^{-1}$. Thus, the losses of thermal quantity at ignition and during combustion of lignite directly depend on the diameter of lignite pieces intended for combustion. Paper contains the analyses of the thermal value, the composition of combustible and non-combustible matters of Kosova's lignite. The research on theoretical and practical field of management of thermal quantity of lignite is based and verified by DIN 1942, 1952, 1956 standards which describe effective thermal quantity. The paper reflects positively on management of the effective thermal quantity.
\end{abstract}

Keywords: Boilers, Combustion, Hydrogen, Sulphur, Thermal

\section{Introduction}

Boilers, combustion of lignite coal and its components in "Kosovo Energy Corporation" are basic processes for economic and environmental sustainability of Energetic Corporation. The paper discusses the combustion process of hydrogen and sulphur in oxidizing zone while is minimized the carbon combustion associated with hydrogen. The main subject of this paper is related to the chemical composition, power and thermal value of lignite coal which is $7524 \mathrm{~kJ}$ $\mathrm{kg}^{-1}$ and depends on the percentage of carbon, hydrogen, sulphur, moisture and sterile parts. [1,2]

In particular will be analyzed the balance of thermal quantity for hydrogen and sulphur, of Kosova lignite. During complete combustion of hydrogen is acquired the good utilization of thermal quantity and as product we have gases with minimal thermal quantity. Furthermore is analyzed the amount of thermal balance of sulphur combustion, whereas as products are benefited sulphur oxides and sulphur, also appears that the thermal amount is lost during the combustion process in boilers. With incomplete combustion we will have gases richer with carbon monoxide, hydrogen and sulphur, which carrying away the thermal quantity in environment, pollute the environment and reduce economic sustainability in the technological process in energetic corporations. $[3,5,10]$

\section{The Composition of Fuel}

The main components of the fuel are carbon, hydrogen, sulphur, moisture and heterogeneous composition of oxygen, nitrogen and ash. The high content of moisture and ash in fuel, reduce its quality and is high impact factors for the quality determination [4].

\subsection{Analytical Composition the Lignite}

Lignite as fuel is composed of non-combustible and combustible matters which determine its thermal value. Carbon in the fuel is a free and as such is determining the thermal value of the fuel, is also associated with hydrogen as methane, ethane, propane, etc. (2.1)

$$
\mathrm{C}+\mathrm{H}+\mathrm{O}+\mathrm{N}+\mathrm{S}+\mathrm{W}+\mathrm{A}=100 \%
$$

Based on the analysis such as experimental, analytical and $\mathrm{XR},[2,5]$ which are realized at the Laboratory of Energetic Corporation of Kosovo, results that the Kosova's lignite has the average percentage of elements that are described in 
bellow table (2.1):

Table 2.1. Average percentage of elements in lignite

\begin{tabular}{llllllll}
\hline Element & $\mathbf{C}$ & $\mathbf{H}$ & $\mathbf{O}$ & $\mathbf{N}$ & $\mathbf{S}$ & $\mathbf{W}$ & $\mathbf{A}$ \\
\hline Percentage \% & 27 & 2.20 & 13,63 & 0,0100 & 0,63 & 40,7 & 14,8 \\
\hline
\end{tabular}

\section{Combustion of Lignite}

Combustion of the lignite coal is a complex process and includes 4 zones: heating zone, reductionzone, oxidation zone and ash zone.

Oxidation - combustion zone is subject of studying in this paper.

During the complete combustion of lignite as products are obtained $\mathrm{CO}_{2}$ and $\mathrm{H}_{2} \mathrm{O}$, whereas during the incomplete combustion of lignite products are $\mathrm{CO}$ and $\mathrm{H}_{2} \cdot[6,7]$

\subsection{Combustion of Hydrogen}

Hydrogen is matter that burns in fuels, is located as free and associated with other fuel elements. $[6,8]$

Complete combustion of hydrogen is accomplished by reaction (3.1).

$$
\mathrm{H}_{2}+\mathrm{O}=\mathrm{H}_{2} \mathrm{O} \quad \Delta \mathrm{H}=2416.04 \mathrm{~kJ} .
$$

To find the enthalpy for absolute combustion of one kilogram of hydrogen below expression is used (3.2):

$$
\Delta \mathrm{H}_{\mathrm{H}}=2416.04 \times 100 \% / \mathrm{MWH} \mathrm{kJ} / \mathrm{kg}
$$

$100 \%$ - is percentage of hydrogen associated with the oxygen (complete combustion of hydrogen)

MWH- is molecular weight of hydrogen

Hydrogen enthalpy for complete combustion is described through the expression (3.3).

$$
\begin{aligned}
\Delta \mathrm{H}_{\mathrm{H}} & =2416.04 \times 100 \% / \mathrm{PMH}=2416.04 \times 1 / / 2 \\
& =1208.02 \mathrm{~kJ} / \mathrm{kg}
\end{aligned}
$$

Alternative I with relative combustion, where $80 \%$ of hydrogen is related to oxygen, then enthalpy is described through the expression (3.4):

$$
\Delta \mathrm{H}_{\mathrm{H}}{ }^{\prime}=2416.04 \times 80 \% / \mathrm{PMH}=966.41 \mathrm{~kJ} / \mathrm{kg}
$$

Alternative II with low combustion, where $50 \%$ of hydrogen is related to oxygen, then enthalpy is described through the expression (3.5):

$$
\Delta \mathrm{H}^{\prime}{ }_{\mathrm{H}}=2416.04 \times 50 \% / \mathrm{PMH}=604.01 \mathrm{~kJ} / \mathrm{kg}
$$

To find the thermal quantity earned with combustion of hydrogen we use the expression (3.6):

$$
\mathrm{Q}=\mathrm{m} \times \Delta \mathrm{H} \mathrm{kJ} / \mathrm{h}
$$

m-weight of hydrogen

$\Delta$ H-enthalpy

By $100 \%$ hydrogen combustion, the thermal amount earned is based in expression (3.7):

$$
\mathrm{Q}=100 \% \times \Delta \mathrm{H}_{\mathrm{H}}=1208.02 \mathrm{~kJ} / \mathrm{h}
$$

Alternative I with $80 \%$ of hydrogen combustion, the thermal amount earned is realized according the expression

$$
\mathrm{Q}^{\prime}=80 \% \times \Delta \mathrm{H}^{\prime}{ }_{\mathrm{H}}=773.13 \mathrm{~kJ} / \mathrm{h}
$$

Alternative II with $50 \%$ of hydrogen combustion, the thermal amount earned is realized according the expression (3.9) :

$$
\mathrm{Q} "=50 \% \times \Delta \mathrm{H}_{\mathrm{C}}=302.005 \mathrm{~kJ} / \mathrm{h}
$$

\subsection{Combustion of Sulphur}

Sulphur as an element in the composition of lignite is matter that is burned and release thermal quantity, which should be well used in the process of lignite combustion in boilers. Sulphur in fuels is located as free and as sulphate, which is considered as mineral matter with negative effects on the quality of fuel and in the environment. [6,8]

Combustion of sulphur becomes by the reaction (3.10):

$$
\mathrm{S}+\mathrm{O}_{2}=\mathrm{SO}_{2} \quad \Delta \mathrm{H}=279 \mathrm{~kJ}
$$

To find the enthalpy for the complete combustion of one kilogram of sulphur is used the expression (3.11):

$$
\Delta \mathrm{H}_{\mathrm{S}}=279 \times 100 \% / \mathrm{MWS} \mathrm{kJ} / \mathrm{kg}
$$

$100 \%$ - is sulphur percentage associated with oxygen (complete combustion of sulphur).

MWS- is molecular weight of sulphur

To find the enthalpy for the complete combustion of one kilogram of sulphur is used the expression (3.12):

$$
\Delta \mathrm{H}_{\mathrm{S}}=279 \times 100 \% / \mathrm{PMS}=279 \times 1 / 32=87.187 \mathrm{~kJ} / \mathrm{kg}
$$

Alternative I with relative combustion, where $80 \%$ of sulphur is associated with oxygen, then enthalpy is calculated through the expression (3.13):

$$
\Delta \mathrm{H}^{\prime}{ }_{\mathrm{S}}=279 \times 80 \% / \mathrm{PMS}=69.75 \mathrm{~kJ} / \mathrm{kg}
$$

Alternative II with poor combustion, where $50 \%$ of sulphur is associated with oxygen, then enthalpy is is calculated through the expression (3.14):

$$
\Delta \mathrm{H}_{\mathrm{S}}=279 \times 50 \% / \mathrm{PMS}=43.53 \mathrm{~kJ} / \mathrm{kg}
$$

To find the thermal amount earned during sulphur combustion the below expression is used (3.15):

$$
\mathrm{Q}=\mathrm{m} \times \Delta \mathrm{H}_{\mathrm{S}} \mathrm{kJ} / \mathrm{h}
$$

$\mathrm{m}$-weight of sulphur,

$\Delta \mathrm{H}_{\mathrm{S}}$ - enthalpy of Sulphur

By $100 \%$ of sulphur combustion, the thermal amount earned is based in expression (3.16) :

$$
\mathrm{Q}=100 \% \times \Delta \mathrm{H}_{\mathrm{S}}=87.187 \mathrm{~kJ} / \mathrm{h}
$$


Alternative I with $80 \%$ of sulphur combustion the thermal amount earned is based in expression (3.17) :

$$
\mathrm{Q}^{\prime}=80 \% \mathrm{x} \Delta \mathrm{H}_{\mathrm{S}}{ }=55.8 \mathrm{~kJ} / \mathrm{h}
$$

Alternative II with $50 \%$ of sulphur combustion the thermal amount earned is based in expression (3.18) :

$$
\text { Q"=50\%x } \Delta \mathrm{H}_{\mathrm{S}}=21.76 \mathrm{~kJ} / \mathrm{h}
$$

Table 3.1 and figure 3.1 presents the data related the thermal quantity gained by combustion of hydrogen and sulphur.

Table 3.1. Thermal quantity of hydrogen and sulphur combustion

\begin{tabular}{llllll}
\hline $\begin{array}{l}\text { Percentage of hydrogen and } \\
\text { sulphur combustion (\%) }\end{array}$ & $\begin{array}{l}\text { Weight of hydrogen } \\
\text { and sulphur }(\mathbf{k g})\end{array}$ & $\begin{array}{l}\text { Enthalpy of } \\
\text { hydrogen } \mathbf{( k J} / \mathbf{k g})\end{array}$ & $\begin{array}{l}\text { Enthalpy of } \\
\text { sulphur } \mathbf{( k J / k g )}\end{array}$ & $\begin{array}{l}\text { Earned quantity for } \\
\text { hydrogen }(\mathbf{k J} / \mathbf{h})\end{array}$ & $\begin{array}{l}\text { Earned quantity for } \\
\text { sulpfur (kJ/h) }\end{array}$ \\
\hline 100 & 1 & 1208.02 & 87.187 & 1208.02 & 87.187 \\
80 & 0.8 & 966.41 & 69.75 & 773.13 & 55.82 \\
50 & 0.5 & 604.01 & 43.53 & 302.005 & 21.76 \\
\hline
\end{tabular}

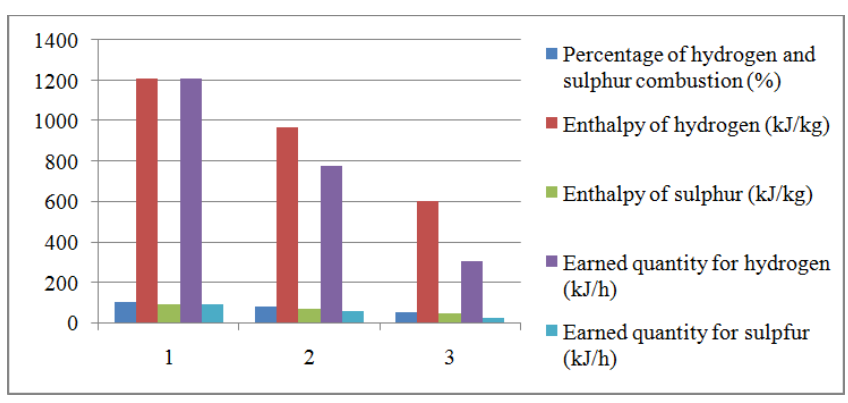

Figure 3.1. Thermal quantity of hydrogen and sulphur combustion

\section{Balance of Thermal Quantity}

Analytical and graphical analysis of hydrogen and sulfur combustion in the oxidation zone, treating the management of the lignite combustion process in boilers in this zone [7,9]. Furthermore, is analyzed in details the thermal quantity gained with combustion of hydrogen and sulpur and is proven to have different values. This changing of thermal quantity is the potential for losses, or thermal quantity without the well managed of process of lignite combustion in boilers. The data related to this issue are presented in table 4.1 and figure 4.1 .

\begin{tabular}{|c|c|c|c|}
\hline $\begin{array}{l}\text { Percentage of hydrogen and sulphur } \\
\text { combustion }(\%)\end{array}$ & $\begin{array}{l}\text { Thermal quantity earned with } \\
\text { hydrogen combustion }(\mathrm{kJ} / \mathrm{h})\end{array}$ & $\begin{array}{l}\text { Thermal quantity earned with } \\
\text { sulphur combustion }(\mathrm{kJ} / \mathrm{h})\end{array}$ & $\begin{array}{l}\text { Changing of thermal } \\
\text { quantity }(\mathrm{kJ} / \mathrm{h})\end{array}$ \\
\hline 100 & 1208.02 & 87.187 & 1120.833 \\
\hline 80 & 773.17 & 55.82 & 717.35 \\
\hline 50 & 302.005 & 21.76 & 280.25 \\
\hline
\end{tabular}

Table 4.1. Changing of thermal quantity eraned with $H$ and $S$ combustion

Table 4.2. Remaining quantity of the thermal value of $H$ and $S$ during combustion

\begin{tabular}{llll}
\hline Percentage of $\mathbf{H}$ and S combustion (\%) & $\mathbf{H}$ and S weight $\mathbf{( k g )}$ & $\begin{array}{l}\text { Remaining thermal quantity of } \mathbf{H} \\
\mathbf{( k J / h )}\end{array}$ & $\begin{array}{l}\text { Remaining thermal quantity of S } \\
(\mathbf{k J} / \mathbf{h})\end{array}$ \\
\hline 100 & 1 & 0 & 0 \\
80 & 0.8 & 434.99 & 31.357 \\
50 & 0.5 & 906.05 & 65.4477 \\
\hline
\end{tabular}

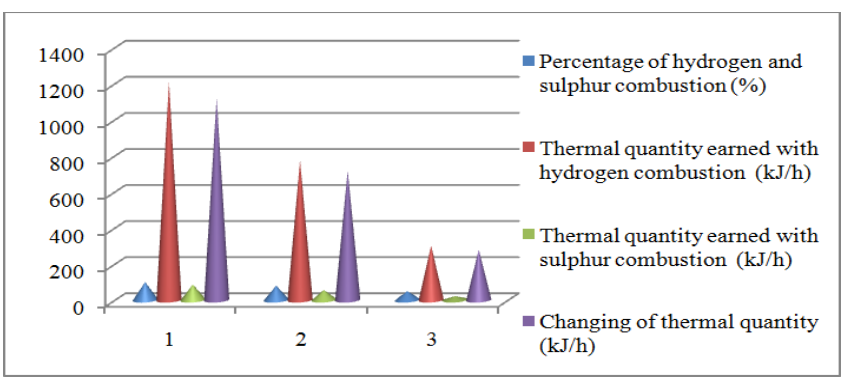

Figure 4.1. Changing of thermal quantity earned with $H$ and $S$ combustion
Based on the analysis of sulphur and hydrogen combustion and thermal value gained with their combustion, and the thermal value of the lignite basin of Kosovo is treated the thermal amount gained with complete and incomplete combustion of hydrogen and sulphur. Furthermore is treated the remaining quantity of the thermal value, which is unused during the technological process of hydrogen and sulphur combustion in oxidizing zone that is potential for losses and for environmental pollution. The data related to this issue are presented in table 4.2 and figure 4.2. 


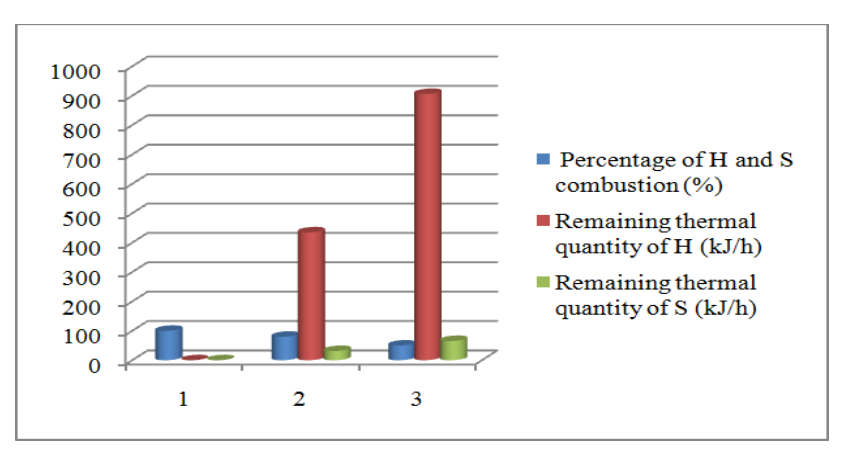

Figure 4.2. Remaining quantity of the thermal value of $H$ and $S$ during combustion 5. Impacts of Sulphur and Hydrogen in the Environment

\section{Impacts of Sulphur and Hydrogen in the Environment}

Sulphur and hydrogen in Kosova's lignite, during the combustion process release the thermal amount that is managed to be transformed into electricity.

The combustion process of sulphur and hydrogen in boilers is inclined to the formation of gases, especially the oxide gases. [5,8]

Oxide gases of sulphur, occupying a special place in this paper related to the treatment, management and their impact on the environment.

The main characteristics of sulphur and hydrogen in normal conditions

1. Sulphur

- The melting point $115.21^{\circ} \mathrm{C}$,

- The boiling point $444.72{ }^{\circ} \mathrm{C}$,

- The starting point of melting $-31.51{ }^{\circ} \mathrm{C}$,

- The critical point $-1041{ }^{\circ} \mathrm{C}$,

- The powder density - $1960 \mathrm{~kg} / \mathrm{m}^{3}$,

- The molar volume - $1553 \mathrm{~cm}^{3}$,

- The thermal conductivity $-0.205 \mathrm{~W} / \mathrm{m} \mathrm{K}$.

2. Hydrogen

- The melting point $-259.2{ }^{\circ} \mathrm{C}$,

- The boiling point $-252.8{ }^{\circ} \mathrm{C}$,

- Density of powder hydrogen $8.99 \mathrm{~kg} / \mathrm{m}^{3}$,

- Molar volume - is associated with air,

- The thermal conductivity - easy combustion

The main parameters of the elements that result in the creation and emission of gases, that polluting the environment are the melting point and thermal conductivity table 5.1 and figure 5.1.

Table 5.1. Melting point and thermal conductivity of $S$ and $H$

\begin{tabular}{lll}
\hline Element & Melting point $\left({ }^{\mathbf{0}} \mathbf{C}\right)$ & $\begin{array}{l}\text { Thermal conductivity } \\
(\mathbf{W} / \mathbf{m ~ K})\end{array}$ \\
\hline Sulphur & 115.21 & 0.205 \\
Hydrogen & -259.2 & Easily combustion \\
\hline
\end{tabular}

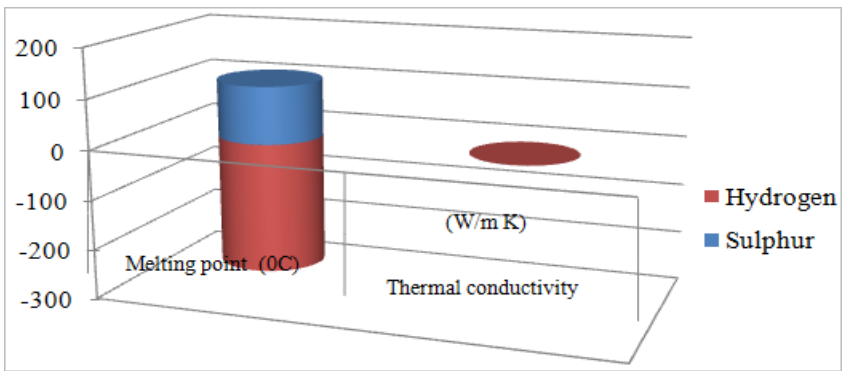

Figure 5.1. Melting point and thermal conductivity of $S$ and $H$

\subsection{Enthalpy of Elementary Sulphur and Hydrogen}

The presence of sulphur and hydrogen in the environment as products of coal combustion in boilers, have their multi impacts on the environmental ecology. Based on the physical and chemical properties, and technological process of hydrogen combustion, is minimized the impact of hydrogen on the environment.

Enthalpy for sulphur. Enthalpy of fusion (mixture) is 1.73 $\mathrm{kJ} \mathrm{mol}^{-1}$. Enthalpy of evaporation is $9.8 \mathrm{~kJ} \mathrm{~mol}^{-1}$. Enthalpy of powdering is $279 \mathrm{~kJ} \mathrm{~mol}^{-1}$ (table 5.2 and figure 5.2).

The hydrogen enthalpy. Enthalpy of mixture is minimized. Evaporation enthalpy is minimized. [3, 4]

Enthalpy of powdering is $2416.04 \mathrm{~kJ}$ mol-1. (table 5.2).

Table 5.2. Enthalpy of $S$ and $H \mathrm{~kJ} \mathrm{~kg}^{-1}$

\begin{tabular}{llll}
\hline Element & $\begin{array}{l}\text { Mixture } \\
\text { Enthalpy kJ } \\
\mathbf{k g}^{-1}\end{array}$ & $\begin{array}{l}\text { Evaporation } \\
\text { Enthalpy kJ kg }\end{array}$ & $\begin{array}{l}\text { Powder } \\
\text { Enthalpy } \mathbf{k J} \\
\mathbf{k g}^{-1}\end{array}$ \\
\hline Sulphur & 0.054 & 0.30 & 8.71 \\
Hydrogen & 0 & 0 & 1208.02 \\
\hline
\end{tabular}

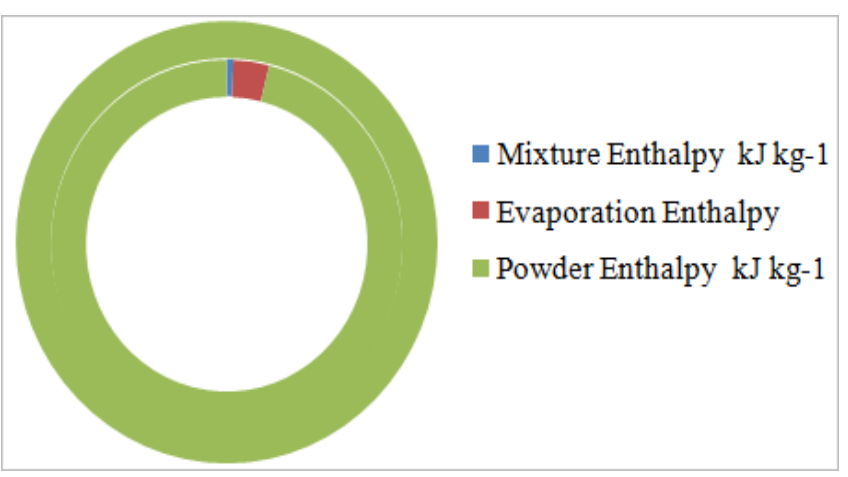

Figure 5.2. Sulphur and hydrogen enthalpy $\mathrm{kJ} \mathrm{kg}^{-1}$

\section{Conclusion}

The paper analyzes the effective thermal value that depends on the percentage of combustion matters and necessary amount of air entered in technological process for the lignite combustion process. In particular in this paper is analyzed the thermal amount that is gained with the complete and incomplete combustion of hydrogen and sulphur, as well and gases released in the oxidation zone during technological process. As a result of analytical and graphical analyzes, led 
us to conclude that with the complete hydrogen combustion the thermal amount earned is $1208.02 \mathrm{~kJ} / \mathrm{h}$, while with the complete sulphur combustion the thermal amount earned is $87.187 \mathrm{~kJ} / \mathrm{h}$. Grounded on the thermal value and its use during the combustion of hydrogen and sulphur, and obtained results will be an overview as follows. With complete combustion of hydrogen use of the thermal value of coal is comprehensive and has an average value of $4.12 \%$. While with the complete combustion of sulphur, use of the thermal value of the coal is weaker and has an average value of $0.297 \%$.

It can be concluded, that with the complete hydrogen combustion, we will have a good use of the thermal quantities during the combustion process of the coal. Complete combustion of sulphur which results with lower thermal value, does not have any major impact on the thermal amount of lignite combustion process in boilers. Sulphur and its oxide gases have huge impact on environmental pollution. The paper as such reflects positively on the management and utilization of the thermal amount in the oxidation zone of boilers and closely is associated to positive effects on the economic and environmental sustainability.

\section{References}

[1] Ekrem B, (1987) Tehnologija sa poznavanje robe. Pejë, 52109.
[2] Laboratory of Energetic Corporation of Kosovo

[3] Feretič D, Tomišič Z, Śkanata D, Čavlina N, Subašič D (2000) Elektrane i okoliš. Zagreb, 213-218.

[4] Halili A, (1983) Furrat metalurgjike II. Tirane, 207-235.

[5] Haxhiaj A, Elezi D, Shkololli SH. (2006) "Mjedisi dhe menaxhimi i gazrave termike në zonën e parangrohjes të furrave vatërxhakete në Trepçë" simpoziumi i gjashtë ndërkombëtar Tirane.

[6] Haxhiaj A, and Haxhiaj E, (2010) "The Thermal Gas Processing in Pre-Heating Zone of "Water-Jacket" Furnaces in "Trepça", TMS Annual Meeting \& Exhibition, Seattle Washington, 205-215.

[7] Haxhiaj A, and Haxhiaj E, (2010) The Optimization of the Coke and Agglomerate Quantity in Lead Production in "Water-Jacket" Furnace, TMS Annual Meeting \& Exhibition, Seattle Washington, 249-257.

[8] Haxhiaj A, and Haxhiaj E, (2010) The Air Pollution from the Port-Piri Furnaces Gases, Journal of International Environmental Application \& Science, 357-363.

[9] Panariti A, Merollari J, (1987) Metalurgjia e gizës-2. Tirane, 7-12.

[10] Ranko R, (2010) Komercijalno Poznavanje robe. Beograd, 2343. 